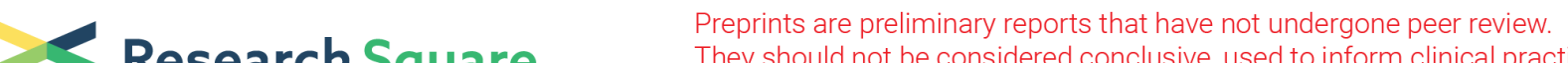 Research Square They should not be considered conclusive, used to inform clinical practice, or referenced by the media as validated information.
}

\section{Symptoms and Comorbidities Differ Based on Race and Weight Status in Persons Living With HIV in the Northern United States: a Cross Sectional Study.}

\section{Kierra R. Butler}

Indiana University School of Medicine

Faye R. Harrell

The Catholic University of America School of Nursing: The Catholic University of America Conway

School of Nursing

Bridgett Rahim-Williams

University of North Florida

Jeffrey M. Robinson

University of Maryland School of Medicine

Xuemin Zhang

National Institutes of Health Office of the Director

Adwoa Gyamfi

University of Connecticut

Judith A. Erlen

University of Pittsburgh

Wendy A. Henderson ( $\square$ Wendy.henderson@uconn.edu )

University of Connecticut https://orcid.org/0000-0003-3924-7118

\section{Research}

Keywords: HIV, HAART, Cardiovascular, Hypertension, Gastrointestinal Symptoms, BMI

Posted Date: August 3rd, 2021

DOl: https://doi.org/10.21203/rs.3.rs-738438/v1

License: (c) (i) This work is licensed under a Creative Commons Attribution 4.0 International License. Read Full License

Version of Record: A version of this preprint was published at Journal of Racial and Ethnic Health Disparities on March 10th, 2022. See the published version at https://doi.org/10.1007/s40615-02201271-0. 


\section{Abstract}

Background: Persons living with HIV (PLWHIV) on highly active antiretroviral treatments (HAART) may require specialized care based on health and demographic indicators. This study investigated the association of co-morbidities, race, weight status, gastrointestinal (GI), and cardiovascular symptoms (CV) and among PLWHIV.

Methods: The Symptom Checklist, Co-Morbidity, and Sociodemographic Questionnaires were used to assessed weight status, GI, and CV symptoms among 283 PLWHIV. Data were analyzed using Latent Class Analysis on John's Macintosh Project 13 Platform.

Results: Participants were majority Black (50\%), 69\% male, and 35\% AIDS diagnosed. Ages were 25 to 66. Clusters included least symptomatic status, weight gain, and weight loss by Black and non-Black participants. The non-Black weight gain cluster reported a higher incidence of AIDS (70.6\% vs $38.2 \%)$, nausea $(70.6 \%$ vs $17.6 \%)$, diarrhea $(70.6 \%$ vs $26.5 \%)$, and shortness of breath ( $58.8 \%$ vs $20.6 \%$ ) compared to the Black weight gain cluster. The Black weight loss cluster reported a higher incidence of CV symptoms such as chest palpitations ( $42.2 \%$ vs $2.7 \%)$, chest pain ( $44.4 \%$ vs $8.1 \%)$, and shortness of breath $(73.3 \%$ vs $35.1 \%)$, and a higher incidence of all GI symptoms with the most prominent being diarrhea ( $71.1 \%$ vs $48.6 \%$ ) compared to the non-Black weight loss cluster.

Conclusions: The existing racial disparities in health-related quality of life for PLWHIV may be improved through precision health and nutrition modifications. Continued research is needed investigating differential health outcomes among PLWHIV on HAART.

\section{Clinical Trial Registration Number: NCT00222716}

\section{Background}

Human Immunodeficiency Virus (HIV), a viral infection previously known as the wasting disease, has become a chronic yet manageable disease due to the advent of Highly Active Antiretroviral Treatments (HAART).(1) HIV is characterized by chronic systemic inflammation including inflammation of the gastrointestinal (GI) barrier.(2) The virus depletes specific Cluster of Differentiation 4 [CD4] + Thymus cells [T-cells] in the gut-associated lymphoid tissue causing the intestinal barrier to become inflamed, leaky, and more permeable. (3) Inflammation in the gut may contribute to persons living with HIV (PLWHIV) having GI symptoms, such as nausea, vomiting, and diarrhea. Many of these symptoms cause weight changes, affecting adherence to HAART.(4) As the gut becomes more permeable, microbes can translocate into the systemic circulation and cause systemic inflammation. Chronic systemic inflammation may contribute to the progression of the disease, systemic dysregulation, and cardiovascular (CV) instability.(5) Microbial translocation is associated with hypertension and GI symptoms in persons living with HIV.(6) Hypertension and the inflammatory process driven by HIV alters the endothelial function of these patients.(5) 
Although HAART has prolonged life, studies suggest that it may also be associated with weight gain,(79) CV disease, and GI symptoms. $(4,7)$ Weight gain after initiating HAART occurs frequently and is associated with lower mortality, thus it is looked upon as a favorable outcome.(9) However, excessive weight gain may lead to an increased risk of chronic conditions such as hypertension, Diabetes Mellitus, and CV disease.(7) In fact, CV disease is the leading cause of death among PLWHIV.(8)

Current literature has shown that weight changes in PLWHIV on HAART have significant implications for health outcomes. CV disease and PLWHIV on HAART must have ongoing investigations to identify factors that will guide care over the lifespan. Gastrointestinal symptoms such as nausea, vomiting, diarrhea, and loss of appetite affect health outcomes for PLWHIV on HAART. Increases in body mass index are common in HIV positive minorities and women. Symptoms were found to vary with patient race, age, and disease progression. $(9,10)$ Racial differences in conjunction with symptom presentation influence treatment options. The clinician selects the proper treatment based on weight status (e.g., weight gain, weight loss), race, and symptoms (especially loss of appetite, acquired immunodeficiency syndrome [AIDS] classification, diarrhea, vomiting, and overeating). The selection of a specified treatment option is of paramount importance because the grid of care options varies, care options even oppose one another for certain groups. The care for Black/African American PLWHIV on HAART that lose weight and have a loss of appetite is quite different than the care for Black/African American PLWHIV on HAART who gain weight and overeat. The proper choice of treatment option improves patients' outcomes and accuracy of care provided by practitioners.

Limited clinical research exists on the topics of changes in weight status, race classification, gastrointestinal health, and CV health among PLWHIV on HAART. Clinicians benefit from knowledge regarding this population that will guide personalized care that targets each specific demographic group based on the needs based on their weight status, their demographics, and presenting symptoms. The health disparities for patients classified as Black/African American in terms of CV disease and HIV disease are well documented in nursing science. There is a higher burden of $\mathrm{CV}$ risk factors and $\mathrm{CV}$ disease in patients Black/Africa American.(11) Additionally, it is 13 times more likely that a Black/African American over the age of 50 will receive an HIV diagnosis than a White/Caucasian over 50 . To address these disparities, providers must provide ongoing and personalized care for this population.(12) As such, monitoring for PLWHIV on HAART may require stratification and personalization based on demographics and symptoms. The differences found may be attributable to patients' race, sex, weight status, comorbidities, and presenting symptoms. Moreover, as PLWHIV on HAART age, comorbidities require closer examination especially in terms of racial differences.(13)

Current literature associated with weight status and multiple morbidities in PLWHIV either examine the change in weight status/body mass index [BMI] related to race after HAART initiation,(14) changes in BMI across a life span,(15) multiple morbidities and obesity without examining the effects of race(16) or multiple morbidities and aging,(17) with some attention to weight/obesity.(8) Although research has been conducted on this topic, there is limited clinical research investigating these variables in a clinical population. Most research included epidemiological large, cross-sectional studies and literature reviews. 
The present study is a secondary data analysis of a clinical population. Therefore, the aim of this study was to investigate the association of race (Black and non-Black [Asian, Mixed-race and Whites]), weight status (weight gain and weight loss), and gastrointestinal and cardiovascular symptoms (nausea, vomiting, shortness of breath, chest pain) and co-morbidities (Hypertension, Coronary artery disease, heart failure) among persons living with HIV/AIDS. The findings of this study will contribute to the growing body of research addressing adverse effects experienced by PLWHIV on HAART and provide important information related to personalized treatment, especially related to race.

\section{Methods}

A secondary analysis was performed on data from the parent study, Improving Adherence to Antiretroviral Therapy (R01 NR04749, PI, J. A. Erlen, University of Pittsburgh), in which the aim of the study was to improve adherence to antiretroviral therapy in PLWHIV through a nurse delivered, telephone-based intervention. The parent study recruited 356 PLWHIV on HAART from the Northern United States, specifically, western Pennsylvania and eastern Ohio community hospitals, university-based clinics, comprehensive HIV care centers, and through self-referral.(18) Inclusion criteria for the parent study included a positive HIV diagnosis by a health care provider being treated with antiretroviral medication, access to a telephone, and consent to participate in the study.

In this cross-sectional secondary analysis, inclusion criteria included participants who submitted responses to all CV and GI symptoms and comorbidity questions on the Symptom Checklist, Co-Morbidity Questionnaire, and Sociodemographic questionnaire (Center for Research in Chronic Disorders, University of Pittsburgh School of Nursing, 1999). Applying these inclusionary criteria to the parent study sample resulted in 283 participants for the current study.

To analyze data from the 283 participants, Latent Class Analysis (LCA) was implemented with John's Macintosh Project [JMP] 13 to perform an analysis of self-reported data on the three aforementioned questionnaires. LCA is an unsupervised, multivariate grouping method that fits a model and determines the most likely 'latent class' of each participant, in a pre-selected number of discreet classes (Statistical Aanalysis System [SAS] Institute Inc., 2016). In this analysis, three groups were selected a-priori.

\section{Results}

Of the participants, approximately $50 \%$ self-identified as Black, $69 \%$ as male, and $35 \%$ as having AIDS. Participants' ages ranged from 25 to 66 years (mean age $=43.70$ years) as shown in Table 1 . The participants were grouped into clusters by race, Black and non-Black. Within the Black and non-Black groups, a pattern developed among the three clusters. Each racial group had a cluster of PLWHIV who reported the lowest incidence of symptoms (weight loss, weight gain, vomiting, etc.) and comorbidities, a cluster characterized with a high incidence of weight gain and weight loss. Thus, each cluster was labelled based on the most prevalent symptom. Within each racial group (Black and non-Black), the clusters were: least symptomatic cluster, weight gain cluster, and weight loss cluster. Afterwards, 
descriptive statistics were calculated using International Business Machines Corporation Statistical Package for the Social Science (IBM SPSS) Version 25) to ascertain the overall and average number of self-reported symptoms and co-morbidities for each cluster within the Black and non-Black groups. A chart of the percentage of all GI and CV symptoms and comorbidities reported can be found in Table 2 .

Table 1

Demographic characteristics of sample

\begin{tabular}{|lclll|}
\hline Demographic measures & & $\begin{array}{l}\text { Overall Group } \\
(N=283)\end{array}$ & $\begin{array}{c}\text { Black } \\
(n=144)\end{array}$ & $\begin{array}{c}\text { Non-Black } \\
(n=139)\end{array}$ \\
\hline Gender \% $(N)$ & Male & $68.90(195)$ & $32.51(92)$ & $36.40(103)$ \\
\hline AIDS \% $(N)$ & Female & $31.10(88)$ & $18.37(52)$ & $12.72(36)$ \\
\hline & & $34.98(99)$ & & \\
\hline & Male & & $11.31(32)$ & $13.78(39)$ \\
\hline & Female & & $5.30(15)$ & $4.59(13)$ \\
\hline AD 4 count $\mathrm{N}=182$ & Age & Mean=43.69 & & \\
\hline
\end{tabular}


Table 2

Cluster Demographic and Variable Percentages

\begin{tabular}{|c|c|c|c|c|c|c|}
\hline & $\begin{array}{l}\text { Black Least } \\
\text { Symptomatic } \\
\text { Cluster } \\
n=65(\%)\end{array}$ & $\begin{array}{l}\text { non-Black } \\
\text { Least } \\
\text { symptomatic } \\
\text { Cluster } \\
\mathrm{n}=\mathbf{8 5}(\%)\end{array}$ & $\begin{array}{l}\text { Black } \\
\text { Weight } \\
\text { Loss } \\
\text { Cluster } \\
\mathrm{n}=43 \\
(\%)\end{array}$ & $\begin{array}{l}\text { non-Black } \\
\text { Weight } \\
\text { Loss } \\
\text { Cluster } \\
n=37(\%)\end{array}$ & $\begin{array}{l}\text { Black } \\
\text { Weight } \\
\text { Gain } \\
\text { Cluster } \\
\mathrm{n}=34 \\
\text { (\%) }\end{array}$ & $\begin{array}{l}\text { non-Black } \\
\text { Weight } \\
\text { Gain } \\
\text { Cluster } \\
n=17(\%)\end{array}$ \\
\hline Sex & 70.8 Male & 76.5 Male & $\begin{array}{l}66.7 \\
\text { Male }\end{array}$ & 70.3 Male & $\begin{array}{l}47.1 \\
\text { Male }\end{array}$ & 70.6 Male \\
\hline Age \pm Std Dv & $44.49 \pm 8.8$ & $45.54 \pm 8.81$ & $\begin{array}{l}41.07 \pm \\
7.3\end{array}$ & $\begin{array}{l}44.24 \pm \\
7.76\end{array}$ & $\begin{array}{l}41.32 \pm \\
5.50\end{array}$ & $\begin{array}{l}41.94 \pm \\
6.82\end{array}$ \\
\hline $\begin{array}{l}\text { Mean CD4 } \pm \\
\text { Std Dv }\end{array}$ & $\begin{array}{l}496.34 \pm \\
313.09\end{array}$ & $\begin{array}{l}420.92 \pm \\
231.72\end{array}$ & $\begin{array}{l}345.16 \\
\pm 302.99\end{array}$ & $\begin{array}{l}425.73 \pm \\
308.46\end{array}$ & $\begin{array}{l}494.31 \\
\pm 311.10\end{array}$ & $\begin{array}{l}500.73 \pm \\
269.75\end{array}$ \\
\hline AIDS & 23 & 29.4 & 42.2 & 40.5 & 38.2 & 70.6 \\
\hline Mean BMI & $26.15 \pm 6.10$ & $25.4 \pm 4.66$ & $\begin{array}{l}25.40 \pm \\
6.75\end{array}$ & $\begin{array}{l}23.86 \pm \\
5.30\end{array}$ & $\begin{array}{l}29.82 \pm \\
5.24\end{array}$ & $\begin{array}{l}27.94 \pm \\
5.82\end{array}$ \\
\hline $\begin{array}{l}\text { High Blood } \\
\text { Pressure }\end{array}$ & 32 & 17.6 & 20 & 21.6 & 32.4 & 29.4 \\
\hline Weight Loss & 32.3 & 2.4 & 42.2 & 83.8 & 0 & 29.4 \\
\hline Weight Gain & 1.5 & 30.6 & 28.9 & 10.8 & 100 & 64.7 \\
\hline Nausea & 13.8 & 10.6 & 62.2 & 56.8 & 17.6 & 70.6 \\
\hline Vomiting & 0 & 2.4 & 26.7 & 27 & 2.9 & 35.3 \\
\hline Diarrhea & 23.1 & 31.8 & 71.1 & 48.6 & 26.5 & 70.6 \\
\hline $\begin{array}{l}\text { Abdominal } \\
\text { Pain }\end{array}$ & 4.6 & 7.1 & 35.6 & 27 & 8.8 & 41.2 \\
\hline Constipation & 0 & 7.1 & 28.9 & 21.6 & 20.6 & 11.8 \\
\hline $\begin{array}{l}\text { Loss of } \\
\text { Appetite }\end{array}$ & 20 & 8.2 & 55.6 & 83.8 & 5.9 & 29.4 \\
\hline Overeating & 4.6 & 10.6 & 24.4 & 10.8 & 55.9 & 58.8 \\
\hline $\begin{array}{l}\text { Shortness of } \\
\text { Breath }\end{array}$ & 20 & 17.6 & 73.3 & 35.1 & 20.6 & 100 \\
\hline $\begin{array}{l}\text { Chest } \\
\text { Palpitations }\end{array}$ & 1.5 & 0 & 42.2 & 2.7 & 0 & 82.4 \\
\hline Chest Pain & 0 & 1.2 & 44.4 & 8.1 & 2.9 & 58.8 \\
\hline Heart Attack & 7.7 & 5.9 & 0 & 0 & 14.7 & 11.8 \\
\hline
\end{tabular}




\begin{tabular}{|c|c|c|c|c|c|c|}
\hline & $\begin{array}{l}\text { Black Least } \\
\text { Symptomatic } \\
\text { Cluster } \\
n=65(\%)\end{array}$ & $\begin{array}{l}\text { non-Black } \\
\text { Least } \\
\text { symptomatic } \\
\text { Cluster } \\
\mathrm{n=} \mathbf{8 5}(\%)\end{array}$ & $\begin{array}{l}\text { Black } \\
\text { Weight } \\
\text { Loss } \\
\text { Cluster } \\
\mathrm{n}=43 \\
(\%)\end{array}$ & $\begin{array}{l}\text { non-Black } \\
\text { Weight } \\
\text { Loss } \\
\text { Cluster } \\
\mathrm{n}=37(\%)\end{array}$ & $\begin{array}{l}\text { Black } \\
\text { Weight } \\
\text { Gain } \\
\text { Cluster } \\
\mathrm{n}=34 \\
(\%)\end{array}$ & $\begin{array}{l}\text { non-Black } \\
\text { Weight } \\
\text { Gain } \\
\text { Cluster } \\
n=17(\%)\end{array}$ \\
\hline $\begin{array}{l}\text { Hospitalized } \\
\text { or treated for } \\
\text { Heart Failure }\end{array}$ & 4.6 & 5.9 & 0 & 0 & 8.8 & 5.9 \\
\hline $\begin{array}{l}\text { Coronary } \\
\text { Artery Disease }\end{array}$ & 4.6 & 3.5 & 2.2 & 0 & 8.8 & 0 \\
\hline $\begin{array}{l}\text { Irregular Heart } \\
\text { Rate }\end{array}$ & 7.7 & 11.8 & 0 & 5.4 & 11.8 & 5.9 \\
\hline $\begin{array}{l}\text { Heart Valve } \\
\text { Disorder }\end{array}$ & 1.5 & 4.7 & 4.4 & 0 & 5.9 & 0 \\
\hline
\end{tabular}

\section{Least Symptomatic Clusters}

Participants in both Black and non-Black least symptomatic clusters reported a lower incidence of $\mathrm{Gl}$ and $\mathrm{CV}$ symptoms and comorbidities (heart attack, irregular heart rate) compared to the weight gain and weight loss clusters. However, participants in the Black least symptomatic cluster reported a higher incidence of high blood pressure (32.0\% vs $17.6 \%)$ and weight loss (32.3\% vs $2.4 \%)$ than their non-Black cluster counterparts. Weight gain (30.6\% vs $1.5 \%)$, diarrhea (31.8\% vs $23.1 \%)$, and AIDS $(29.4 \%$ vs $23.1 \%)$ were reported more in the non-Black least symptomatic cluster compared to the Black least symptomatic cluster.

\section{Weight Loss Clusters}

Participants who self-identified as Black in the weight loss cluster reported a higher incidence of all GI symptoms than non-Blacks with the most prominent being diarrhea ( $71.1 \%$ vs $48.6 \%)$ and nausea $(62.2 \%$ vs $56.8 \%$ ). CV symptoms including chest palpitations (42.2\% vs $2.7 \%$ ), chest pain ( $44.4 \%$ vs $8.1 \%$ ), and shortness of breath (73.3\% vs $35.1 \%$ ) were more common in the Black cluster compared to the non-Black cluster. Interestingly, there were few to no reports of CV comorbidities (i.e., heart attack, heart failure, coronary artery disease) in the non-Black group. The most prominent symptoms of the non-Black weight loss cluster compared to Black weight loss cluster were loss of appetite ( $83.8 \%$ vs $55.6 \%$ ) and weight loss (83.8\% vs $42.4 \%)$. Although participants in the non-Black cluster reported some CV symptoms (shortness of breath, chest palpitations, and chest pain), the incidence of $\mathrm{CV}$ co-morbidities (irregular heart rate $2.5 \%)$ was very low.

\section{Weight Gain Clusters}


Results revealed a high incidence of weight gain and overeating among participants in the weight gain clusters. Compared to the Black weight gain cluster, the non-Black weight gain cluster reported the highest incidence of AIDS (70.6\% vs $38.2 \%$ ), nausea (70.6\% vs $17.6 \%$ ), diarrhea (70.6\% vs $26.5 \%)$, and shortness of breath (58.8\% vs $20.6 \%$ ). The Black weight gain cluster reported low incidence of GI symptoms (i.e., vomiting, abdominal pain), but a higher incidence of CV co-morbidities than the any other cluster $(14.7 \%)$.

\section{Discussion}

The aim of this study was to investigate the association among race (Black, non-Black), weight status, (weight gain and weight loss) and symptoms/co-morbidities in persons living with HIV. With advances in medications used to treat and manage HIV, PLWHIV are living longer.(19) However, longevity of life predisposes individuals to developing chronic disease conditions common in aging.(20) Additionally, long term use of HAART by individuals living with HIV can affect weight.(14) This combination of multiple morbidities and weight status affects health-related quality of daily life for PLWHIV.

\section{Multiple Morbidities and Microbial Translocation/Disease Progression}

Antiretroviral treatments aid in replenishing the CD4 T-cell count and decreasing the viral load, which reduces inflammation in the gut associated lymphoid tissue and promotes immune reconstitution. Through the administered surveys, it appeared as though Black and non-Black participants in the least symptomatic clusters were able to manage their HIV. Of the participants in the Black and non-Black least symptomatic cluster, $23 \%$ vs $29.4 \%$, respectively reported an AIDS diagnosis. The lower incidence of AIDS had an association with fewer reports of $\mathrm{Gl}$ and $\mathrm{CV}$ symptoms and comorbidity compared to the weight gain and weight loss clusters. This finding may indicate a reduced occurrence of the translocation of microbes and/or restored or improved CD4 + T-cell count due to an early initiation of HAART.(21) It is also possible that the absence of an AIDS diagnosis is indicative of the efficacy and tolerability of HAART in participants in the least symptomatic cluster, which in turn suppresses the progression of HIV.

\section{Race/Ethnicity and Weight Status}

In this study, PLWHIV differed by race, weight status, and types of chronic disease conditions. Race included Black and non-Black individuals. Several studies $(14,22)$ have likewise found these differences by race/ethnicity, co-morbidities, and weight status among PLWHIV. Additionally, among the participants diagnosed with AIDS in this study, non-Black men had the highest prevalence of the disease. However, according to the Centers for Disease Control and Prevention, Black men have the highest prevalence of AIDS diagnoses.(23) This atypical burden of a higher number of reported AIDS diagnoses in non-Black males may be attributed to more non-Black males with AIDS enrolled in the study compared to their Black male counterparts (52\% vs $47 \%$ ). The higher prevalence of non-Black men with AIDS enrolled in this study 
could also be indicative of factors such as later diagnosis and treatment,(24) or a lower tolerability of HAART.

\section{HAART and Weight}

Initiating HAART has been associated with increasing BMI, and long-term use can lead to obesity.(25) The Black Weight Gain cluster had a higher BMI than the non-Black weight gain cluster (29.8\% vs $27.9 \%)$. The higher BMI and self-reported weight gain could be attributed to a "return to health," depression), or other factors such as unemployment (22) or metabolic syndrome.(26) According to several studies(14, 22) race attributed to the differences between weight gain and BMI. Participants who identified as Black were found more likely to have higher BMI and weight gain than their counterparts. These differences may be due to higher CD4 T-cell count, a longer duration of HAART,(7) and/ or a higher pretreatment CD4 T-cell count.(14) The non-Black weight gain group reported a higher incidence of GI symptoms (loss of appetite, diarrhea, vomiting) compared to their counterparts in the Black weight gain group. Such symptoms typically are associated with weight loss.(27) A lower BMI has been shown to be associated with a higher mortality risk for patients on HAART.(25)

Gastrointestinal symptoms such as nausea, vomiting, weight loss, and diarrhea are common in PLWHIV. $(4,28)$ Although such symptoms were reported in both the weight loss and weight gain clusters, these symptoms were reported more frequently in the weight loss clusters. The GI symptoms could be attributable to the disease itself or a side effect of HAART medication.(29) A possible explanation for the higher incidence of weight loss and loss of appetite in the non-Black weight loss cluster could be a combination of multiple factors such as early vs late HAART initiation, antiretroviral efficacy and tolerability, disease progression, and race.

\section{Strengths}

This study adds to the growing body of literature investigating health status among PLWHIV. Our findings contribute new knowledge to the limited research examining the role of weight and its effects on $\mathrm{GI}$ symptoms and cardiovascular risks among PLWHIV. Insights into the relationships among this tetrad (race, weight, GI symptoms, and cardiovascular risks) suggests a call for primary prevention to address and promote healthy weight status to improve health-related quality of life for PLWHIV.

\section{Limitations}

The research design included a secondary data analysis that utilized a sample size of approximately 283 individuals with complete information on three questionnaires. As such the sample size prevents (or limits) generalizability of the results as the secondary data analysis was not purposefully prospectively powered. Limited data points prevented in-depth statistical analysis.

\section{Conclusions}

Weight changes affect both GI and cardiovascular symptoms for PLWHIV. As such, nutritional interventions may be beneficial for managing weight and reducing adverse effects for PLWHIV.(30) 
Moreover, although the use of HAART medication is beneficial for treating and managing HIV infection, the long-term use of HAART medications may be problematic for healthy weight maintenance. Therefore, monitoring of weight status is important for PLWHIV for reducing chronic disease conditions such as cardiovascular disease, hypertension, and diabetes; co-morbid conditions that adversely affect healthrelated quality of life. Precision health initiatives hold promise for health-care treatments for PLWHIV; such advances may indeed continue to prolong years of healthy living.

\section{Abbreviations}

AIDS: Acquired Immunodeficiency Syndrome

BMI: Body mass index

CV: Cardiovascular

CD4: Cluster of Differentiation 4

GI: Gastrointestinal

HAART: Highly Active Antiretroviral Treatments

HIV: Human Immunodeficiency Virus

IBM SPSS: International Business Machines Corporation Statistical Package for the Social Science JMP: John's Macintosh Project

LCA: Latent Class Analysis

PLWHIV: Persons Living With HIV

SAS: Statistical Analysis System

T-cell: Thymus cell

\section{Declarations}

Ethics approval and consent to participate

The ethical approval for the study as obtained from the University of Pittsburg and the approval, OHSR Exempt Number 11919.

\section{Consent for publication}

Not applicable 
Availability of data and materials

The datasets used and/or analyzed during the current study are available from the corresponding author on reasonable request.

\section{Competing interests}

The authors declare that they have no competing interests.

\section{Funding}

The authors acknowledge funding from the United States Department of Health and Human Services, National Institutes of Health (NIH), National Institute of Nursing Research, parent study was funded on the grants 2R01NR04749 to Dr. Judith Erlen, additional funds from the Division of Intramural Research to Dr. Wendy A. Henderson, 1ZIANR000018; National Institutes of Health Academy Enrichment Program to Kierra R. Butler; National Institute on Minority Health \& Health Disparities, NIH fellowship DREAM award 1K22MD006143; to Dr. Bridgett Rahim-Williams; Postdoctoral Intramural Research Training Award to Dr. Jeffrey M. Robinson. Additional funding was provided to Dr. Wendy A. Henderson by the Association of Nurses in AIDS Care and Sigma Theta Tau International; Epsilon Phi Chapter; Sigma Theta Tau International Research Award. PEO International Peace Scholarship and Predoctoral award to Adwoa Gyamfi the University of Connecticut, Storrs, Connecticut, USA. None of the funding organizations played a role in the design of the study and collection, analysis, and interpretation of data and in writing the manuscript.

\section{Authors' contributions}

All authors on this paper meet the four criteria for authorship as identified by the International Committee of Medical Journal Editors (ICMJE); authors as specified below have contributed to the conception and design of the study, drafted or have been involved in revising this manuscript, reviewed the final version of this manuscript before submission and agree to be accountable for all aspects of the work. Specifically, using the CRediT taxonomy, the specific contribution of each author is as follows: Conceptualization \& Methodology: WAH, KRB, JMR, XZ, and BRW. Formal Analysis: JMR, KRB, and XZ. Funding acquisition: KRB, BRW, JMR, AG, JAE and WAH. Investigation: Project administration: Supervision: WAH and JAE. Validation: JMR and XZ. Writing original draft: KRB, FRH, JMR, BRW, XZ, AG, $J A E$, and WAH. Writing/Revising: pending. All authors read and approved the final manuscript.

\section{Acknowledgements}

Not applicable

\section{Footnotes}

Not applicable 


\section{References}

1. Lakey, W., Yang, L. Y., Yancy, W., Chow, S. C., \& Hicks C. Short communication: from wasting to obesity: initial antiretroviral therapy and weight gain in HIV-infected persons. AIDS Res Hum Retroviruses. 2013;29(3):435-40.

2. Mudd JC, Brenchley JM. Gut Mucosal Barrier Dysfunction, Microbial Dysbiosis, and Their Role in HIV1 Disease Progression. J Infect Dis. 2016;214(Suppl 2):S58-66.

3. Yoder AC, Guo K, Dillon SM, Phang T, Lee EJ, Harper S, et al. The transcriptome of HIV-1 infected intestinal CD4 + T cells exposed to enteric bacteria. 2017;

4. Hall VP. Common Gastrointestinal Complications Associated with Human Immunodeficiency Virus/AIDS: An Overview. Crit Care Nurs Clin North Am [Internet]. 2018;30(1):101-7. Available from: https://doi.org/10.1016/j.cnc.2017.10.009

5. Ballocca F, D'Ascenzo F, Gili S, Grosso Marra W, Gaita F. Cardiovascular disease in patients with HIV. Trends Cardiovasc Med [Internet]. 2017;27(8):558-63. Available from: http://dx.doi.org/10.1016/j.tcm.2017.06.005

6. Manner IW, Baekken M, Kvale D, Oektedalen O, Pedersen M, Nielsen SD, et al. Markers of microbial translocation predict hypertension in HIV-infected individuals. HIV Med. 2013;14(6):354-61.

7. Achhra AC, Mocroft A, Reiss P, Sabin C, Ryom L, Wit S De, et al. Short-term weight gain after antiretroviral therapy initiation and subsequent risk of cardiovascular disease and diabetes: the $D$ : A: D study *. HIV Med. 2016;17(May 2015):20-5.

8. Lake JE. The Fat of the Matter: Obesity and Visceral Adiposity in Treated HIV Infection. Curr HIV/AIDS Rep. 2017;14(6):211-9.

9. Yuh B, Tate J, Butt AA, Crothers K, Freiberg M, Leaf D, et al. Weight change after antiretroviral therapy and mortality. Clin Infect Dis. 2015;60(12):1852-9.

10. So_Armah K., \& Freiberg, MS. HIV and Cardiovascular Disease: Update on Clinical Events, Special Populations, and Novel Biomarkers. Curr HIV/AIDS Rep. 2018; 15(3), 233-244. doi:10.1007/s11904018-0400-5

11. Carnethon MR, Pu J, Howard G, Albert MA, Anderson CAM, Bertoni AG, et al. Cardiovascular Health in African Americans: A Scientific Statement From the American Heart Association. Vol. 136, Circulation. 2017. 393-423 p.

12. Abara WE, Smith L, Zhang S, Fairchild AJ, Heiman HJ, Rust G. The influence of race and comorbidity on the timely initiation of antiretroviral therapy among older persons living with HIV/AIDS. Am J Public Health. 2014;104(11):e135-41.

13. Kirk JB, Goetz MB. Human immunodeficiency virus in an aging population, a complication of success. J Am Geriatr Soc. 2009;57(11):2129-38.

14. Koethe JR, Jenkins CA, Lau B, Shepherd BE, Justice AC, Tate JP, et al. Rising Obesity Prevalence and Weight Gain among Adults Starting Antiretroviral Therapy in the United States and Canada. AIDS Res Hum Retroviruses. 2016;32(1):50-8. 
15. Brennan AT, Berry KM, Rosen S, Stokes A, George J, Raal F, et al. Growth curve modelling to determine distinct body mass index trajectory groups in HIV-positive adults on ART in South Africa. AIDS. 2021;33(13):2049-59.

16. Kim DJ, Westfall AO, Chamot E, Willig AL, Mugavero MJ, Ritchie C, et al. Multimorbidity Patterns in HIV-Infected Patients. JAIDS J Acquir Immune Defic Syndr. 2012;61(5):600-5.

17. Guaraldi G, Malagoli A, Calcagno A, Mussi C, Celesia BM, Carli F, et al. The increasing burden and complexity of multi-morbidity and polypharmacy in geriatric HIV patients: a cross sectional. BMC Geriatr [Internet]. 2018;18:1-10. Available from: https://www.ncbi.nlm.nih.gov/pmc/articles/PMC5910563/pdf/12877_2018_Article_789.pdf

18. Henderson WA. Testing a Model of Health-Related Quality of Life in Persons Living with HIV and Liver Disease. University of Pittsburgh, Michigan, USA.; 2007.

19. Ballocca F, Gili S, D’Ascenzo F, Marra WG, Cannillo M, Calcagno A, et al. HIV Infection and Primary Prevention of Cardiovascular Disease: Lights and Shadows in the HAART Era. Prog Cardiovasc Dis [Internet]. 2016;58(5):565-76. Available from: http://dx.doi.org/10.1016/j.pcad.2016.02.008

20. D’Ascenzo F, Cerrato E, Calcagno A, Grossomarra W, Ballocca F, Omedè P, et al. High prevalence at computed coronary tomography of non-calcified plaques in asymptomatic HIV patients treated with HAART: A meta-analysis. Atherosclerosis. 2015;240(1):197-204.

21. Allers K, Puyskens A, Epple HJ, Schürmann D, Hofmann J, Moos V, et al. The effect of timing of antiretroviral therapy on CD4+ T-cell reconstitution in the intestine of HIV-infected patients. Mucosal Immunol. 2016;9(1):265-74.

22. Olaleye AO, Owhonda G, Daramola O, Adejo I, Olayiwola H, Inyang JI, et al. Factors associated with weight gain among adult patients initiating antiretroviral therapy in Port Harcourt, Nigeria: a retrospective cohort study. Infect Dis (Auckl). 2017;49(8):635-8.

23. Centers for Disease Control and Prevention. Estimated HIV incidence and prevalence in the United States, 2014-2018. HIV Surveill Suppl Rep [Internet]. 2021;26(1):1-81. Available from: http://www.cdc.gov/hiv/library/reports/hivsurveillance.html.http://www.cdc.gov/hiv/library/reports/hivsurveillance.htmlhttp://wwwn.cdc.gov/dcs/ContactUs/Form

24. Shiu ATY, Choi KC, Lee DTF, Yu DSF, Man Ng W. Application of a health-related quality of life conceptual model in community-dwelling older Chinese people with diabetes to understand the relationships among clinical and psychological outcomes. J Diabetes Investig. 2014;5(6):677-86.

25. de Pee, S. \& Semba RD. Role of nutrition in HIV infection: review of evidence for more effective programming in resource-limited settings. Food Nutr Bull [Internet]. 2010;31(4):S313-344. Available from: https://www.ncbi.nlm.nih.gov/pubmed/21214036

26. Dimala CA, Atashili J, Mbuagbaw JC, Wilfred A, Monekosso GL. Prevalence of hypertension in HIV/AIDS patients on highly active antiretroviral therapy (HAART) compared with HAART-naïve patients at the Limbe Regional Hospital, Cameroon. PLoS One. 2016;11(2):1-11. 
27. Evans D, McNamara L, Maskew M, Selibas K, Van Amsterdam D, Baines N, et al. Impact of nutritional supplementation on immune response, body mass index and bioelectrical impedance in HIV-positive patients starting antiretroviral therapy. Nutr J. 2013;12(1):1-14.

28. WHO. HIV and AIDS [Internet]. 2019. Available from: https://www.who.int/news-room/factsheets/detail/hiv-aids

29. Gupta R, Ordonez RM, Koenig S. Global impact of antiretroviral therapy-associated diarrhea. AIDS Patient Care STDS. 2012;26(12):711-3.

30. Mankal PK, Kotler DP. From wasting to obesity, changes in nutritional concerns in HIV/AIDS. Endocrinol Metab Clin North Am [Internet]. 2014;43(3):647-63. Available from: http://dx.doi.org/10.1016/j.ecl.2014.05.004

\section{Figures}

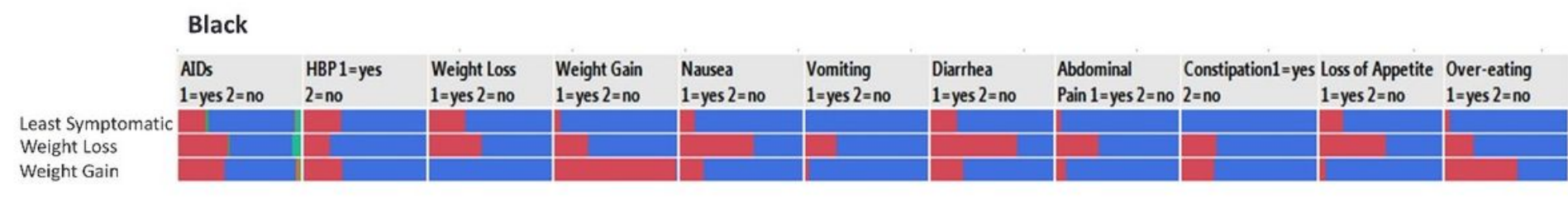

\begin{tabular}{|c|c|c|c|c|c|c|c|}
\hline 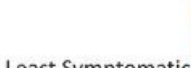 & $\begin{array}{l}\text { Shortness of } \\
\text { Breath } 1=\text { yes } 2=\text { no }\end{array}$ & $\begin{array}{l}\text { Chest Palpitations } \\
1=\text { yes } 2=\text { no }\end{array}$ & $\begin{array}{l}\text { Chest Pain } \\
1=\text { yes } 2=\text { no }\end{array}$ & $\begin{array}{l}\text { Heart Attack } \\
1=\text { yes } 2=\text { no }\end{array}$ & $\begin{array}{l}\text { Hospitalizes or treated for } \\
\text { heart failure } 1=\text { yes } 2=\text { no }\end{array}$ & $\begin{array}{l}\text { Coronary Artery } \\
\text { Disease } 1=\text { yes } 2=\text { no }\end{array}$ & $\begin{array}{l}\text { Irregular Heart } \\
\text { Rate } 1=\text { yes } 2=\text { no }\end{array}$ \\
\hline $\begin{array}{l}\text { Least Symptomatic } \\
\text { Weight Loss }\end{array}$ & & & & & & & \\
\hline Weight Gain & & & & & & & \\
\hline
\end{tabular}

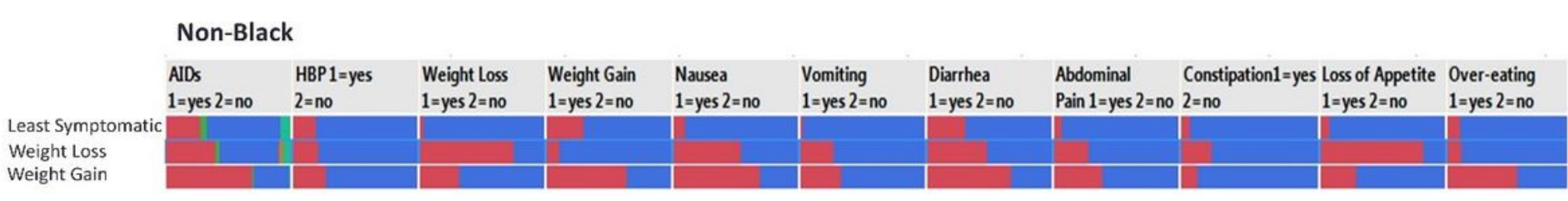

\begin{tabular}{|c|c|c|c|c|c|c|c|}
\hline & $\begin{array}{l}\text { Shortness of } \\
\text { Breath } 1=\text { yes } 2=\text { no }\end{array}$ & $\begin{array}{l}\text { Chest Palpitations } \\
1=\text { yes } 2=\text { no }\end{array}$ & $\begin{array}{l}\text { Chest Pain } \\
1=\text { yes } 2=\text { no }\end{array}$ & $\begin{array}{l}\text { Heart Attack } \\
1=\text { yes } 2=\text { no }\end{array}$ & $\begin{array}{l}\text { Hospitalizes or treated for } \\
\text { heart failure } 1=\text { yes } 2=\text { no }\end{array}$ & $\begin{array}{l}\text { Coronary Artery } \\
\text { Disease 1=yes 2=no }\end{array}$ & $\begin{array}{c}\text { Irregular Heart } \\
\text { - Rate } 1=\text { yes } 2=\text { no }\end{array}$ \\
\hline Least Symptomatic & & & & & & & \\
\hline Weight Loss & & & & & & & \\
\hline Weight Gain & & & & & & & \\
\hline
\end{tabular}

\section{Figure 1}

Latent Class Analysis Results 